\title{
Biological utilities of Parthenium hysterophorus
}

\author{
Veena B. K ushwaha* and Shivani M aurya \\ Department of Zoology, D. D. U. Gorakhpur University, Gorakhpur ( U.P.), INDIA \\ *Corresponding author. E-mail: vbk2006@ sify.com
}

\begin{abstract}
Parthenium hysterophorus L. (Asteraceae) is a serious weed of pastures, wasteland and agricultural fields in world. Various problems are posed by the weed to human health, agriculture, live stock production and biodiversity. It is used as folk remedy against various afflictions. The review discusses several prominent biological utilities of $P$. hysterophorus as it contains several important chemical constituents mainly histamine, saponin, glucosides and triterpene (sesquiterpene) and can be of use for the purpose of biocontrol of various pathogens , for its medicinal utility and even for the purpose of food .
\end{abstract}

Keywrods: Biocontrol, Biological utility, Folk remedy, Parthenium hysterophorus

\section{INTRODUCTION}

Plant Parthenium hysterophorus L. (Asteraceae) is labeled as serious weed of pasture, wastelands and agricultural field in world. The weed is noxious on two counts. Firstly, it is a highly adaptable weed and can grow anywhere, invade all types of pasture lands and cause substantive losses in the yield of agriculture (Aneja et al., 1991; Auld et al., 1983; Haseler, 1976; Jayachandra, 1971; Krishnamurthy et al., 1975) secondly it is a health hazard (Dhawan and Dhawan, 1999). Direct contact with plant or plant parts, living or dead, results in dermatitis in mankind and the presence of pollens in the air cause diseases like air borne contact dermatitis (Agarwal and D'Souja, 2009), fever and asthma (Lonkar et al., 1974; Rodriguez, 1975; Rodriguez etal., 1976a; Shen etal., 1976; Subba Rao et al., 1976, 1978). Live stock is also allergic and susceptible to P. hysterophorus. Close contact of animal with $P$. hysterophorus may cause rashes on their whole body and udders. The active ingredient of Parthenium is parthenin (Rodriguez, 1975). It is responsible for bitter milk disease in live stocks fed on grass mixed with P. hysterophorus (Narasimhan et al., 1984). Buffalo bull calves and cross bred bull calves fed on Parthenium mixed with conventional green fodder develop toxic symptoms leading to death with in 8-20 days (Narasimhan et al., 1977). Beside this Parthenium has shown several prominent biological activities in animal and human models. It contains several important chemical constituents mainly histamine, saponin, glucosides and triterpene (sesquiterpene) that give this plant an importance as folk medicinal plant. Much before the menacing proportions of Parthenium appeared in India, the plant was known to have medicinal utility in Mexico in 1897. It was used as a folk remedy against various affliction such as ulcerated sores, certain skin diseases facial neuralgia, fever and anemia. A report of 1921 indicates that the flowers of this plant were being used as tonic, blood purifier, abortive, vermifuge, ammenagague and as an insecticide in various parts of Europe (Hansen del Orbe, 1977). P. hysterophorus is widely known as white top, white head, congress grass or carrot grass.

The genus Parthenium has about twenty species belonging to western hemisphere. It is included in family Asteraceae. P. hysterophorus L. is supposed to have originated as a result of natural hybridization between $P$. conifertum and P. biplnatifidum (Nath, 1988). The diploid chromosome number for the Indian species has been reported to be 18 (Hakoo, 1963). Two types of population of P. hysterophorus L. makes a complex. The plants show two distinct phases in life, juvenile, rosette or the vegetative stage and adult, mature or the reproductive stage.

The juvenile stage is rosette with dark green, pinnetisect, radical, large sized leaves and a much reduced stem. Large lower leaves are spread on the ground forming mats and they do not allow growth of any vegetation under it. Flowers are absent in juvenile stage. The adult stage is erect and much branched, up to one meter or more in height. Stems are whitish, hairy, octangular and longitudinally grooved. Leaves are simple, alternate, pinnately or bipinnately dissected, $20-30 \times 12-25 \mathrm{~cm}$, becoming smaller towards the apex of the branches. The stem and leaf surface is covered with four types of glandular and non glandular, multicellular white trichomes (Rodriguez et al., 1976 b).

The inflorescence, in terminal as well as axillary populations, is peduncle, $0.5-1.5 \mathrm{~cm}$, corymb like, ending 
in scorpoid cyme bearing heterogamous capitula. Each capitulam is pentangular, $4-6 \mathrm{~mm}$ across, creamy white, having five fertile florets. About 40 fertile disc florets are also present. The ray florets are pistillate, zygomorphic, epigynous, 2.0-3.5 mm in length, corolla lobes indistinct, stigma bifid, solitary basal anatropus ovule; bract ovate and transparent showing prominent venation. The fertile disc florets are staminnated, actinomorphic, epigynous; corolla five lobed, infundibulform; bract oblanccolate, boat shaped, 2-3 mm in length; stamen five and syngenesious. The sterile disc florets are neutral. The cypsela is obovate to ellipsoid, light brown when young and drak brown when mature, crowned by persistant corolla appendages and style, 2-3 $\mathrm{mm} \times 1-2 \mathrm{~mm}$., pappus are absent (Haseler, 1976; Singh and Chandra, 1982). The dried ray florets having mature seeds are shed along with two sterile disc florets and subtending bract as a unit called achene complex.

The time interval between anthesis and seed shedding is only 13-15 days. Average sized plant produces as many as 25,000 seeds (Haseler, 1976). The plant exclusively reproduces by sexual method but possess a remarkable power of regeneration. Pollination and dissemination of seed both are anemorphillous. Depending upon the frequency and distribution of rains during the year, the plant can complete one, two or even three generations (Singh et al., 1993).

The seed of Parthenium do not germinate immediately after ripening as the achenes first need to disperse and release several inhibitors of germination (Picman and Picman, 1984; Kohli et al., 1985). The germination of $P$. hysterophorus reaches a maximum 1-6 months after the achenes ripen. The seeds are not able to germinate in soil below a depth of $5 \mathrm{~cm}$. P. hysterophorus flowers are grown about 30-45 days after germination. The whole plant cycle is completed within about 5 months. A single plant produces an average of 810 flower heads (Labrada, 1988). A photoperiod of 13 hours and warm conditions are conductive in flowering (Williams and Groves, 1980).

\section{ORIGIN AND SPREAD}

P. hysterophorus Linn. (Asteraceae) considered a serious weed in several tropical and subtropical countries across the world (The wealth of India, 2003) is supposed to have originated in North East Maxico(Dale, 1981; Haseler, 1976; McClay, 1984) and during the last hundred years has found its way to Africa, Australia and Asia. It has been reported from United States, Central America, South America, West Indies, Lesser Antilles of the new world and from India, Nepal, Africa, China, Vietnam and Australia of the old world (Towers et al., 1977; Aneja et al., 1991). It is a weed of roadsides, vacant lots and non cropped areas along non disturbed habitat (Singh et al., 1993) and has also been recorded as a minor pest of cultivation in United States, Brazil, Argentina (Muenscher, 1955) and India (Krishnamurthy et al., 1993; Saraswat, 1993; Dhawan and Dhawan, 1994). The weed was first brought to India as an ornamental plant in 1910 but it failed to catch up. Again it invaded India and Australia in fifties as contamination of wheat and pasture seeds, imported for the United State of America (Rao, 1956; Haseler, 1976). In India it was first reported as a weed from North India in 1979 (Sharma and Tyagi, 1979). As a species facing little environmental resistance Parthenium has become a menace in wastelands and non cropped areas (Singh et al., 1993). Nitrogenous wastes of humans and livestock promotes its growth (). This is the reason of the extensive growth of the weed close to cities and other human settlements. Under suitable soil and moisture conditions it becomes dominant species and results in the exclusion of beneficial plants (Jayachandra, 1971; Kanchan, 1975; Krishnamurthy, et al., 1975; Dale, 1981). Till 1977 the weed did not find any place in the world's worst seeds (Holm, et al., 1977). Now a day, it has become one of the seven most dangerous weeds of the word.

\section{PHYTOCHEMISTRY OF P. HYSTEROPHORUS}

Whole plant: Two types of sesquiterpene lactones, hysterin and dihydroisoparthenin have been isolated from plant P. hysterophorus (Picman et al., 1982). Histamine $(0.585 \%)$ is present in aerial parts of the plant (Kamal and Mathur, 1991). Syringaresinal has also been isolated from this weed (Das et al., 1999).

Three ambrosanolides; $\alpha$-epoxymethylacrylyloxy parthenin, its 11a13-dihydro derivatives and $8 \alpha$ eposeymethylacrylylos-ambrosin; have been isolated from chloroform extract of the aerial parts of the $P$. hysterophorus (Chhabra et al., 1999). A normal sesquiterpenoid, charminarone (the first seco-pseudoguaianolide) has been isolated from the whole plant (Venkataiah et al., 2003).

Relative compositions of these lactones vary in different species of $P$ arthenium. Parthenin is characteristic of $P$. hysterophorus while hysterin, hymenin and ambrosin of P. kipinnatifidum. Hysterin is the major sesquiterpene of P. glomeratum. Quercetagetin 3,7-dimethyl ether is a major flavanol present in this plant (Shen et al., 1976).

Small amount of 6-hydroxylaemferol, 3,7-dimethyl ether and the glucosides, quercetin3-0-glucoside, Kaemferol 3-0-glucoside and kaempferol 3-0-arabino glucoside have also been isolated from P. hysterophorus (Rodriguez, 1975). Phenolic glucosides show fluctuations in number and amount depending on the collection of site. Accumulation of fumeric acid in stem and leaves and ferulic acids in all parts of the plant except pollens, have also been reported. These phenolic acids are said to be responsible for allelopathic impact of plant $P$. 
hysterophorus on other plants (Kanchan, 1975).

L eaves: Parthenin, hexacosanol, myricyl alcohol, $\beta$ sitisterol, campesterol, stigmasterol, betulin, ursolic acid, $\beta$-D-glucoside of $\beta$-sitosterol and saponin have been isolated from leaves of $P$. hysterophorus. The saponin on hydrolysis yield oleanolic acid and glucose.

The aqueous extract of $P$. hysterophorus contains free amino acids, glucose, galactose and potassium choloride (4.8\%) (Gupta et al., 1977). Methoxypseudoguaianolides viz. 13-ethoxy-dihydroambrosin, 13-methoxydihydroparthenin and $2 \beta, 13 \alpha$-dimethoxy- dihydroparthenin have been isolated from leaves of this plant (Bhullar et al., 1997). The leaves also contain parthenin, caffeic, chlorogenic, p-hydroxybenzoic, vanilic, salicylic, gentisic, neo-chlorogenic and proto-catechuic acids (The wealth of India, 2003). The allelochemical parthenin is sequestered at high level in capitate-sessile tirchomes on leaf surfaces of $\mathrm{P}$. hysterophorous (Rainhardt et al., 2005). Leaves contain about $5 \%$ parthenin (The wealth of India, 2003).

Flower: Methanolic extract of flower of P. hysterophorous contains several constituents such as $2 \beta$ hydroxycoronopilin, 8$\beta$-hydroxycoronopilin, 11-H,13hydroxyparthenin, parthenin and coronopilin. Parthenin up to $8 \%$ is present in capitulum (The wealth of India, 2003). A new highly oxygenated pseudoguaianolides (8$\beta$-acetoxyhysterone $C$ ), parthenin, coronopilin and hysterone $\mathrm{C}$ have also been isolated from the flowers (Ramesh et al., 2003; Das et al., 2005,2007).

R oot: Histamine $(0.35 \%)$ is present in the roots of plant $P$. hysterophorus (Kamal and Mathur, 1991). The roots contain parthenin, caffeic, chlorogenic, phydroxybenzoic, p-anisic, vanilic, salicylic, gentisic, neochlorogenic and proto-catechuic acids (The wealth of India, 2003).

Biological activities: Sesquiterpene lactones exhibit a wide spectrum of biological activities, which include cytotoxic, antitumour, allergen, antimicrobial, antifeedant, phytotoxic and insecticidal properties (Rodriguez et al., 1976a). The sesquiterpene lactone parthenin is the main secondary metabolite of $\mathrm{P}$. hystorophorus $\mathrm{L}$. (Compositae) and possess all the properties mentioned above. Parthenin the major sesquiterpene lactone becomes useful when properly processed. The early reports suggest that parthenin can be used in pest and pathogen control, either by it self or as a lead compound for the development of active and more selective analogues (de la Fuente et al., 2000; Datta and Saxena, 2001; Fazal et al., 2011).

Insecticidal: Parthenin the active compound present in Parthenium hysterophorus is known to show activity against termites, cockroaches (Tilak, 1977) as well as migratory grasshoppers, M elanoplus sanguinipes $[\mathrm{F}]$ (Picman et al., 1981; Fagoonee, 1983). Whole plant extract of Parthenium hysterophorus showed insect growth regulatory activity against the cotton stainer, D ysdercus angulatus [F] (Kareem, 1984), fifth instar larvae of S. litura (Ranjandran and Gopalan, 1979; Balasubramanian, 1982) and toxic effect on cabbage leaf webber (Crocidolomia binolalis Zell), and pulse beetle (Callosobruchus maculates F) infesting cowpea seeds (Bhaduri et al., 1985) and mites (Gupta, 1968). The natural occurring resin material of the guayul plant (Parthenium spp.) has been demonstrated to protect wood against termite, molluscan borer and fungal attacks (Bultman et al., 1998). Petroleum ether extract of leaves, stem and inflorescence of P. hysterophorus shows toxic effect on mean life span and progeny production of adults of the mustard aphid, Lipaphis erysimi (Sohal et al., 2002). The environmental biologists have identified its cholinesterase antagonistic properties which can be used in control of insects and worms (Dhawan and Dhawan, 1995).

Antifeedant: Parthenium has been shown to act as a feeding deterrent to the adult of Dysdercus koenigii F., Tribolium castaneum Hbst, Phthorimaea operculella (Zell), Callosobruchus chinensis L. (Sharma and Joshi, 1977) and sixth instar larvae of Spodoptera litura (F) (Datta and Saxena, 1997).

Nematicidal: Extract of $P$. hysterophorus show toxicity against root knot nematodes Meloidogyne incognita (Kofoid and white), Chitwood, H elicotylendus dihyslera (Cobb) sher (Hasan and Jain, 1984). Crushed leaves admixed into the soil are used to reduced root galling in papaya caused by M . incognita (de la Fuente et al., 2000). $\mathrm{H}$ er bicidal: Pure parthenin as well as extract of different parts of P. hysterophorus show phytotoxic effects on many aquatic (Pandey, 1994,1995,1996) as well as terrestrial weeds (Khosla et al., 1980; Khosla and Sobti, 1981; Kumari, 1990; Singh et al., 1992; Batish et al., 1997; Acharya and Rahman, 1997). The sesquiterpene lactone parthenin has received most attention regarding allelopathy or potential herbicidal properties of the plant (Duke et al., 2007).

Antifungal: Antifungal potential of different extracts of P. hysterophorus against human pathogenic fungi were investigated by Rai and Upadhyay (1990) and Rai (1993, 1994, 1995). The dermatophytes and other fungal pathogens have been found to be sensitive to sesquiterpene lactones which are present as active agent in Asteraceous plant P. hysterophorus (Rai et al., 2003). A ntiamoebic: Antiamoebic activity of parthenin from P. hystero phorus has been evaluated in vitro against axenic and polyxenic cultures of Entamoeba histolytica. Parthenin has been found to show acute toxicity to the cultured organisms. Parthenin has activity comparable to that of metronidazol (Sharma and Bhutani, 1988).

A ntimalarial: Parthenin and some of its derivatives were 
evaluated for antimalarial activity against a multi drug resistant strain of Plasmodium falciparum. Parthenin and related compounds have significant antimalarial action (The wealth of India, 2003).

Trypanocidal: Crude ethanolic extract of plant $P$. hysterophorus shows activities against Trypanosoma evansi. The extract exerts antitrypanosomal effect at intraperitoneal doses of 100 and $300 \mathrm{mg} / \mathrm{kg}$ body weight when used for treatment of infected rats (Talakal et al., 1995).

Antibactarial: The volatile oil which contains sesquiterpene and flavanoids were found to be highly effective against gram positive and gram negative bacteria (Chopra, 1960) and various species of dermatophytes (Dikshit and Dixit, 1982).

Antiviral: Parthenium extract exhibits significant antiviral action against potato virus Y. This virus extensively damages the chilli crops. Parthenin might find use as an effective agent against potato virus $\mathrm{Y}$ (The wealth of India, 2003).

Cytotoxic: Pseudoguaianolides and their analogues exhibit cytotoxic effect (Das et al., 2007). Themethanolic extract of P. hysterophorus has been found to have antitumour effect in host mice bearing transplantable lymphocytic leukemia. The active compound leads to slow development of tumour and increases the survival of mice bearing lymphocytic leukemia (Mukherjee and Chatterjee, 1993). Studies conducted at the Cancer Research Institute, Bombay and in vitro ctotoxicity against human cancer cells have shown that $P$. hysterophorus possess anticancerous properties (Haq et al., 2011, Ramamurthy et al., 2011).

Parthenin exhibits cytotoxicity with chromosomal aberrations in peripheral blood lymphocytes when administered to mice. A single intra-peritoneal dose of 4$31 \mathrm{mg} / \mathrm{kg}$ body weight of animal of parthenin increases the frequency of micronucleated reticulocytes in mice (Ramos et al., 2002).

Pharmacology: Oral administration of ethanolic extract of this plant leads to various behavioural as well as physiological changes like decrease in body weight erythrocyte count, haemoglobin and lymphocyte percentage and increase in relative liver weight, neutrophill and leukocyte count in rat (Kushwaha and Maurya, 2010, Maurya and Kushwaha, 2010). The leaf extract of plant $P$. hysterophorus shows depolarizing neuromuscular junctional blocking action in rats similar to that of neostigmine (Vijayalakshmi et al., 1999). P. hysterophorus induce changes in neurotransmitter levels in mouse brain which in turn affects the physiology of the peripheral endocrine glands in mice (Verma et al., 2006). $10 \%$ cold aqueous extracts of flowers successfully elicit a hypotensive response in dogs (The wealth of India, 2003).Methnolic extract of the plant is reported to cause significant relaxant activity on skeletal muscles and depressant on central nervous system (Jha et al., $2011 \mathrm{a}, \mathrm{b})$.

P. hysterophorus L. whole plant is used as allergen (Dwivedi et al., 2008). It also shows hypoglycemic effect in normal and diabetic rats (Patel et al., 2008). The flower extract has apasmogenic action in isolated rabbit duodenum (The wealth of India, 2003).

The flower extract possess cardiac depressant effect as concluded from experiments on perfused frog heart. Aqueous extract of flowers and leaves exert lethal effect on frog tadpoles. Phytoconstituents particularly phytotoxins present in extracts have been reported to be responsible for this action (The wealth of India, 2003). The plant is also reported to be effective in neuralgia, dysentery and as stimulant to menstrual functions (Dhawan and Dhawan, 1995).

\section{ASFOOD}

As food, the leaf protein from this plant is reported to be better than cereal and legume proteins. It is used as spices in many parts of the world . The leaf protein concentrate contains; protein 48-54\%, ether extract $11-13 \%$, ash 6$8 \%$ etc. (Khan et al., 2011). Parthenin free dried fibres of the plant contain 1.6-2.4\% of $\mathrm{N}_{2}$ and can be used as cattle feed (Narasimhan et al., 1993).

\section{Conclusion}

The presence of several important chemical constituents mainly histamine, saponin, glucosides and triterpene (sesquiterpene) in the weed plant P. hysterophorus and their prominent biological activities in animal and humanmodels indicate that the weed can be of use as insecticidal, antifeedant, nematicidal, herbicidal antifungal, antiamoebic, antimalarial, trypanocidal, antibacterial, antiviral. Active compounds and their analogues due to cytotoxic and pharmacological activities in future may find an important place as medicine. The nutrional value of the plant indicates its utility as food and fodder also.

\section{REFERENCES}

Acharya, S.S. and Rahman, A. (1997). Allelopathic effect of $P$ artheni um hyster ophorus Linn. On seed germination and seedling growth of Cassia tora Linn., Environ. Ecol., 15: 335-337.

Agarwal, K.K. and D'Souza, M. (2009). Airborne contact dermatitis induced by Parthenium: a study of 50 cases in south. India. Clin. Exp. Dermatol., 34(5): 4-6.

Aneja, K.R., Dhawan, S.R. and Sharma, A.B. (1991). Deadly weed - Parthenium hyster ophor us Linn and its distribution. IJ WS, 23: 14-18.

Auld, B.A., Hooking, J. and Mc Fadyen, R.E. (1983). Analysis of the spread of tiger pear and Parthenium weed in Australia. Australian Weeds, 2: 56-60.

Balasubramanian, M. (1982). Plant species reportedly possessing pest control properties. EWC/UH-DATA BASE, 
University of Hawaii, pp 249.

Batish, D.R., Kohli, R.K., Singh, H.P. and Saxena, D.B. (1997). Studies on herbicidal activity of parthenin, a constituent of Parthenium hysterophorus towards billygoat weed (Ageratum conyzoides). Curr. Sci., 73: 369-371.

Bhaduri, N., Ram, S. and Patil, B.D. (1985). Evaluation of some plant extracts as protectants against the pulse beetle, Callosobruchus maculates Fabr, infesting cowpea seeds. J . Entomol. Res., 9: 183-187.

Bhullar, M.K., Kalsi, P.S. and Chhabra, B.R. (1997). Methoxy pseudoguaianolides from Parthenium hysterophorus. Fitoterapia, 6 8(1): 91-92.

Bultman, J.D., Chen, S. L. and Schloman, Jr. W.W. (1998). Antitermitic efficacy of the resin and rubber in fractionator overhead from a guayul extraction process. Industrial crops and Products, 8 (2) : 133-143.

Chhabra, B.R., Kohli, J.C. and Dhillon, R.S. (1999). Three ambrosanolides from Parthenium hysterophorus. Phytochemistry (Oxford), 52 (7) : 1331-1334.

Chopra, C.L. (1960). In vitro antibacterial activity of oils from Indian Medicinal Plants I. Journal of the American Pharmaceutical Association of Science E ducation, 49 : 780781.

Das, B., Venkataish, B. and Kashinatham, A. (1999). (+)Syringaresinol from Parthenium hysterophorus, Phytochemistry (Amsterdam), 63 (4): 383-386.

Das, R., Geethangili, M., Majhi, A., Das, B., Rao, Y. K. and Tzeng, Y. M. (2005). A new highly oxygenated pseudoguaianolide from a collection of the flowers of Parthenium hysterophorus. Chemical and Pharmacological Bulletin (Tokyo), 53 (7): 861-862.

Das, B., Reddy, V. S., Krishnaiah, M., Sharma, A. V. S., Ravikumar, K., Rao, J. V. and Sridhar, V. (2007) Acetylated pseudoguainolides from Parthenium hysterophorus and their cytotoxic activity. Phytochemistry, 68 (15) : 2029-2034.

Dale, I.J. (1981). Parthenium weed in America. Report on the ecology of Parthenium hysterophorus in south centeral and north America. A ustr alian Weeds, 1: 8-14.

Datta, S. and Saxena, D.B. (1997). Parthenin and azadirachtin A as antifeedants against Spodopter a litura (Fab). Pestic. Res. J ., $9: 263-266$.

Datta, S. and Saxena, D.B. (2001). Pesticidal properties of parthenin (from Parthenium hysterophorus) and related compounds. Pest Manag. Sci., 57: 95-101.

De la Fuente J.R., Uriburu M.L., Burton G. and Sosa V.S. (2000). Sesquiterpene lactone variability in Parthenium hysterophorus L. Phytochemistry, 55 (7) : 769-772

Dhawan, S.R. and Dhawan, P. (1995). The Parthenium menace and its management- an overview. Ad. Plant. Sci., 8 (1) : 120.

Dhawan, S.R. and Dhawan, P. (1994). Congress grass: Effect of temperature and light on seed germination. Ad. Plant. Sci., 7 (1): $177-178$

Dikshit, A. and Dixit, S.N. (1982). Cedrus oil- a promising antifungal agent. Indian Perfumer ., 26(2-4): 216-227.

Duke, S.O., Wedge, C.E., Cerdeira, A.L. and Matallo, M.B. (2007). Herbicide effects on plant desease. Outlooks Pest Manege., $18: 36-40$.

Dwivedi, S., Dwivedi, A. and Dwivedi, S.N. (2008). Folk lore uses of some plants by the tribes of Madhya Pradesh with special reference to their conservation. Ethnobotanical Leaflets., 12: 763-771.

Fagoonee, I. (1983). Natural pesticides from neem tree (Azadirachta indica A J uss) and other tropical plants. In Proc. II Internat. Neem conference, Rauschhalzhausen, ed. by Schmutterer, H. and Ascher, K.R.S., 211-223.

Fazal, H., Ahmad, N., Ullaha, I., Inayat, H., Khan, L. and Abbasi, B. H. (2011). Antibacterial potential in Parthenium hysterophorus, Stevia rebaudiana and Ginkgo biloba. Pak. J. B ot., 43 (2) : 1307-1313.

Gupta, R.K. (1968). Studies of the curative effects of Cedrus deodara oilk against sarcoptic mange in buffalo calves. Indian J ournal of Veterinary Science, 38 (2) : 203-209.

Gupta, R.K., Dutta, T.R. and Patil, B.D. (1977). Chemical investigation of Parthenium hysterophor us. Indian J ournal of Pharmacy, 39 (3): 64-66.

Hakoo, M.L. (1963). A diploid Parthenium in Jammu. C ur r Sci., $32: 273$

Hansen del Orbe, R. (1977). Par thenium hyster ophorus Linn. Diseases, Pests and Weeds in Tropical Crops, edited by Jiirgen. Kranz, Heinz Schmutterer, and Werner Koch. . Verlag Paul. Parey, Berlin and Hamburg

Haq, R. M., Ashraf, S., Malik, C. P., Ganie, A. A. and Shandilya, U. (2011). In vitro cytotoxicity of P arthenium hyster ophorus extracts against human cancerous cells. J. Chem. Pharm. Res., 3 (6) : 601-608.

Hasan, N. and Jain, R.K. (1984). Bio-toxicity of Parthenium hysterophorus extract against Meloidogyne incognita and Helicotylenchus dihystera. Nematodological M editerranea, $12: 239-242$.

Haseler, W.H. (1976). Parthenium hysterophorus L. in Australia. PANS, 22: 515-517.

Holm, L.G., Plucknett, D.L., Panchu, J.V. and Herberger, J.P. (1977). The world's worth weeds. Honolulu Univ. Press. pp. 109.

Jayachandra. (1971). Parthenium weed in Masore state and its control. Curr. Sci., 40 (21) : 568-569.

Jha, U., Chhajed, P. J., Oswal, R. J. and Shelke T.T. (2011a). Skeletal muscle relaxant activity of methanolic extract of Parthenium hysterophorus L. leaves in swiss albino mice. Int. J. Pharm. \& Life Sci. 2 (11) : 1211-1213.

Jha, U., Chhajed, P.J., Shelke, T. T., oswal, R.T. and adkar, P.P. (2011b). CNS activity of methanol extract of Parthenium hysterophorus L. in experimental animals. Der Pharmacia Lettre, 3 (4) : 335-341.

Kamal, R. and Mathur, N. (1991). Histamine a biogenic amine from $\mathrm{P}$ arthenium hysterophorus Linn. J ournal of $\mathrm{P}$ hytological Research, , 4 (2): 213-214.

Kanchan, S.D. (1975). Growth inhibitors from Parthenium hysterophorus L. C urr. Sci., 44 : 358-359.

Kareem, A.A. (1984). Progess in the use of neem and other plant species in pest control in India, in Research Planning Works on Botanical Pest control Project, IRRI, Los Banos, Philippines, 6-10 Aug, pp. 15.

Khan, R.A., Ahmed, M., Khan, M.R., Yasin, M., Muhammad, B. and Khan, R.(2011) Nutritional investigation and biological activities of Parthenium hysterophorus, Af. J. Pharm. \& Pharmacol., 5 (18) 2073-2078.

Khosla, S.N. and Sobti, S.N. (1981). Parthenin- a promising root inhibitor from Parthenium hysterophorus Linn. 
Pesticides, , 15: 8-11.

Khosla, S.N., Singh, K. and Sobti, S.N. (1980). Parthenin from Parthenium hysterophorus is phytotoxic too, Ind J . For., 3: 261-265.

Kohli, R.K., Anita Kumari and Saxena, D.D. (1985). Auto and Teletoxicity of Parthenium hysterophorus L. Acta Universitatis Agriculturae, Brno, A (Fac. Agronomy), 33: 253-263.

Krishnamurthy, K., Ramachandra Prasad T.V. and Muniyappa, T.V. (1975). Agriculture and health hazards of Parthenium. Curr. Res., 4: 169-171.

Krishnamurthy, K.., Munegawda, M.K. and Jagdish, A. (1993). Ecological weed survey in Karnataka. International Sym. On Integrated Weed Management for Sustainable Agriculture. Indian Soc. of Weed Science, H isar. Proc.. I: 43-52.

Kumari A. (1990). Physiological and biochemical aspects of allelopathy of Parthenium hysterophorus $\mathrm{L}$ and role of herbicide towards its eradication. Res. Bull. (Sci) Panjab University, 41: 123-124.

Kushwaha, V. B. and Maurya, S. (2010). Toxicity study of ethanolic extracts of $\mathrm{P}$ arthenium hysterophorus in rats. Trends in Biosciences, 3 (2) :216-219.

Labrada, R. (1988). Complemento al studio biologico de Parthenium hyster ophorus L. Resumenes IX Congresso ALAM, Julio 26-30, Maracaibo, Venezuela.

Lonkar A., Mitchell J.C. and Colnan C.D. (1974). Contact dermatitis from Parthenium hysterophorus L. Trans. And Annual Report of the St. John's Hospital Dermatalogical Soc. London., 60 (7) : 43-53.

Maurya, S. and Kushwaha, V. B. (2010) Effect of ethanolic extract of Parthenium hyster ophorus on haematological parameters in rat. The Bioscan, 5 (3) : 437-440.

Mc Clay, A.S. (1984). Biocontrol agents for Parthenium hyster ophorus L. from Maxico. Proc.VI Int. Sym. Biol. Cont. of Weed Vancover.

Muenscher, W.C. (1955). Weeds. $2^{\text {nd }}$ Ed. Mc Millon. New York, pp. 548.

Mukherjee B. and Chatterjee M. (1993). Antitumour activity of Parthenium hysterophorus and its effect in the modulation of biotransfotming enzymes in transplanted murine leukaemia. Planta M edica, 59 (6) : 513-516.

Narsimhan, T.R., Ananth, M., Narayana Swami, Rajendra Babu, Mangla, A. and Subba Rao, P.V. (1977). Toxicity of Parthenium hysterophorus L. Curr. Sci., 46 (1): 15.

Narasimhan, T.R., Keshava Murthy, B.S., Harindranth, N. and Subba Rao, P.V. (1984). Characterization of a toxin from Parthenium hysterophorus and its mode of excretion in animal. J. Biosci., 6 (5): 729-738.

Narsimhan T.R., Murthy B.S. and Rao P.V. (1993). Nutritional evaluation of silage made from the toxic weed Parthenium hysterophorus in animals. Food Chem. Toxicol ., 31(7): 509515.

Nath, R. (1988). Parthenium hysterophorus L. A general account. Agricultural Review, 9(4): 171-179.

Pandey D.K. (1994). Inhibition of salvinia (Salvinia molesta M itchell) by Parthenium (Parthenium hyster ophorus L.). II. Relative effects of leaf, flower, stem and root residue on salvinia and paddy. J. Chem E col., 20: 3123-3131.

Pandey D.K. (1995). Inhibition of lemna by Parthenium, in Abstr of VI Biennial Conf Indian Soc Weed Science,
Annamalai University, Tamil Nadu. India. 116-117.

Pandey D.K. (1996). Phytotoxicity of sesquiterpene lactone parthenin on aquatic weeds. Chem Ecol., 22: 151-160.

Patel, V., Chitra V., Prasanna P. and Krishnaraju V. (2008). Hypoglycemic effects of aqueous extract of Parthenium hysterophorus L. in normal and alloxan induced Diabetic rats. Indian J . of Pharmacology, 40 (4):183-185

Picman A.K., Balza F. and Towers G.H.N. (1982). Occurrence of Hysterin and Di-Hydroisoparthenin in Parthenium hysterophorus, Phytochemistry, 21(7): 1801-1802.

Picman A.K., Elliott R.H. and Towers G.H.N. (1981). Cardiac inhibiting properties of sesquiterpene lactone, parthenin, in the migratory grasshopper, M elanoplus sanguinipes. Canad J. Zool., $59: 285-292$.

Picman, J. and Picman, A.K. (1984). Autotoxicity in Parthenium hyster ophorus and its possible role in control of germination. Biochemical Systematics and E cology, 12: 287-292.

Rai M.K. (1993). Laboratory evatuation of fungitoxic activity of crude extract of Parthenium hysterophorus. J . Environ. Biol., 14 (1): 41-44.

Rai M.K. (1994). In vitro evaluation of aqueous extract of Parthenium against Rizophus oryzae: a cousal organism of otomycosis in a college student. Indian M edicine, 44 (2): 4-5.

Rai M.K. (1995). Comparative antimycotic activity of different parts of Parthenium hysterophorus L. World Weeds, 2:53-57.

Rai M.K. and Upadhyay S.K. (1990). In vitro efficacy of different extract of Parthenium hyster ophorus Linn. Against human pathogenic fungi using different techniques. Indian J. Pathol. and Microbiol., 33 (2) : 179-181.

Rai M.K., Deepak Acharya and Wadegaonkar P. (2003). Plant derived antimycotics: Potential of Aster aceous plants. In Plant derived antimycotics :Current Trends and Future prospects : Howorth Press, N-York, Londin, Oxford, pp. 165-185.

Rainhardt C., Kraus S., Walker F., Foxcroft L., Robbertse P. and Hurle K. (2005). The allelochemical parthenin is sequestered at high level in capitate sessile trichomes on leaf surfaces of Parthenium hyster ophorus. Allelopathy J ournal., Vol: 15:2.

Rajandran B. and Gopalan M. (1979). Note on juvenomimetic activity of some plants. Indian J . Agri Sci., 49: 295-297.

Ramamurthy, S. K., Pittu, P., Kotturi, R., Devi, P. and Kumar, S. ( 2011) In vitro cytotoxic activity of methanol and acetone extracts of Parthenium hysterophorus flower on A549 cell lines. Af. J. Pharm. and Pharmcol., 5 (18) : 2073-2078.

Ramesh C., Ravindranah N., Das B, Prabhakar A, Bharatam J., Ravikumar K., Kashinatham A.. and Mc Morris T.C. (2003). Pseudoguaianolides from the flowers of Parthenium hysterophorus. Phytochemistry (Amsterdam), 64 (4): 841844.

Ramos A., Rivero R., Visozo A., Piloto J. and Garcia A. (2002). Parthenin, a sesquiterpene lactone of Parthenium hysterophorus L. is a high toxicity clastogen. M utat Res., 514 (1-2): 19-27.

Rao, R.S. (1956). Parthenium hysterophorus Linn. A new record for Indian J. Bombay Nat. Hist. Soc., 54 : 218-220.

Rodriguez, E. (1975). Chemistry and distribution of sesquiterpene lactones, flavenoids in Parthenium (compositae): Systemic and ecological implication. Ph.D. 
Thesis. Univ. of Texas. Austia.

Rodriguez, E., Dillon, M.O., Mabry, T.J., Mitchell, J.C. and Towers, G.H.N. (1976 a). Dermatologically active sesquiterpene lactones in trichomes of Parthenium hysterophorus L. (compositae). Experientia, 15: 236-238.

Rodriquez, E., Towers, G.H.N. and Mitchell, J.C. (1976 b). Biological activities of sesquiterpene lactones. Phytochemistry, 15: 1573-1580.

Saraswat, V.N., 1993. M ajor weeds of Indian agriculture their distribution and ecology. Integrated weed management for sustainable agriculture. Proceedings of an Indian Society of Weed Science International Symposium, Hisar, India, 1820 November 1993 Hisar, Haryana, India; Indian Society of Weed Science, Vol. I:35-41

Sharma, G.L. and Bhutani, K.K. (1988). Plant based Antiamoebic drugs part ii. Amoebicidal activity of parthenin isolated from Partheni um hyster ophorus , Planta M edica., 54 (2): 120-122.

Sharma, R.N. and Joshi, V.N. (1977). Allomonic principal in Parthenium hysterophorus. Potential as insect control agent and role in the seed's resistance to serious insect depredation. Part II. The biological activity of parthenin on insecta. Biovigyanam., 3: 225-231.

Sharma, S. and Tyagi ,B. (1979). Flora of North East Rajasthan. Kalyani Pub. pp. 540

Shen, M.C., Rodriguez, E., Kerr, K. and Mabry, T.J. (1976). Flavonoids of four species of Parthenium (compositae) Phytochemistry, 15: 1045-1047.

Singh, S.K. and Chandra, V. (1982). Asteraceae of Azamgarh. Proc. N at. Acad. Sci. India, 52 (1): 29-41.

Singh, C.M., Angiras, N.N. and Kumar, S. (1993). Perrineal weed management in non cropped situations, Integrated weed management for sustainable agriculture. Proceedings of an Indian Society of Weed Science International Symposium, Hisar, India, 18-20 November 1993 Hisar, Haryana, India; Indian Society of Weed Science, Vol. I: 379-388.

Singh, K. Shahi, A.K., Pal, S and Balyan, S.S. (1992). Phytoal lel opathic influence of Partheni um hyster ophorus $L$, in Allelopathy in Agroecosystems, Agriculture and F orestry, ed by Tauro P. and Narwal S.S., CCS Haryana Agricultural University, Hisar, India Feb. 12-14. pp. 61-63.
Sohal, S.K., Rup, P.J., Kaur, H., Kumari, N. and Kaur, J. (2002). Evaluation of the pesticidal potential of the congress grass, Parthenium hysterophorus Linn. On the mustard aphid, Lipaphis erysimi (Kalt.). Environ. Biol., 23(1): 15-8.

Subba Rao, P.V., Mangla, A., Subba Rao, B.S. and Prakash, K.M. (1976). Clinical and immunological studies on person exposed to Parthenium hyster ophorus L. Experianta. 33: 1387-1388.

Subba Rao, P.V., Mangla, A., Towers, G.H.N. and Rodriquez, E. (1978). Immunological activity of parthenin and its dissemination in person sensitized to Parthenium hyster ophorus L. Contact Dermatitis. 4: 199-203.

Talakal, T.S., Dwivedi, S.K. and Sharma, S.R. (1995). In vitro and in vivo therapeutic activity of Parthenium hyster ophorus against Trypanosoma evansi. Indian J . Exp. Biol., 33(11) 894-896.

The Wealth of India (2003). Vol. 4, NISCOM, New Delhi, 282-284.

Tilak, B.D. (1977). Pest control strategy in India, in Crop Proction Agents- Their biological evaluation, ed by $\mathrm{Mc}$ Farlane NR, Academic Press, Lodon, 99-109.

Towers, G.H.N., Mitchell, T.C., Rodriguez, E., Benett, F.D. and Subba Rao, P.V. (1977). Biology and Chemistry of Parthenium hysterophorus L. a problem weed in India.j . of Scientific and Industrial Res. India. 36:672-684.

Venkataiah, B., Ramesh, C., Ravindranath, N. and Das, B. (2003). Charminarone, a seco-pseudoguaianoide from Parthenium hyster ophorus. Phytochemistry (Amsterdam), 63 (4): 383-386.

Verma, S., Shrivastava, R., Prashad, P.K. and Shrivastava, V. K. (2006). Parthenium hyster ophorus induced changes in neurotransmitter levels in mouse brain. Phytotherapy Research, 21 (2) : 183-185.

Vijayalakshmi, P., Vijayalakshmi, N. and Kumar, N.V. (1999). Depolarizing neuromuscular junctional blocking action of Parthenium hysterophorus leaf extracts in rat. Phytother. Res., 13 (5): 367-370.

William, J.D. and Groves R. H. (1980). The influence of temperature and photoperiod on growth and development of Parthenium hysterophorus L. Weed Research, 20: 47-52. 